\title{
ANALISIS KESIAPAN MAHASISWA PRODI \\ PENDIDIKAN GURU MADRASAH IBTIDAIYAH SEBAGAI CALON PENDIDIK PROFESIONAL
}

\author{
Nurul Hidayah \\ Email: nurulhidayah@ radenintan.ac.id
}

\section{PRODI PGMI UIN RADEN INTAN LAMPUNG}

\begin{abstract}
Abstrak
Penelitian ini bertujuan untuk mendeskripsikan kesiapan mahasiswa Program Studi Pendidikan Guru Madrasah Ibtidaiyah (PGMI) Fakultas Tarbiyah dan Keguruan UIN Raden Intan Lampung sebagai calon pendidik profesional dibidang Pendidikan Dasar (SD/MI) melalui mata kuliah pembelajaran mikro (microteaching).

Penelitian dilakukan dengan menggunakan pendekatan deskriptif kualitatif. Teknik sampling yang digunakan adalah teknik purposive sampling. Subyek penelitian mahasiswa yang mengambil mata kuliah pembelajaran mikro tahun akademik 2016/2017 sebanyak 5 orang. Metode pengumpulan data melalui lembar dokumentasi dan observasi. Analisa data melalui tiga tahap yaitu, reduksi data, penyajian data, dan penarikan kesimpulan/verifikasi.

Berdasarkan hasil analisis penelitian dapat disimpulkan bahwa dalam melakukan perencanaan pembelajaran mahasiswa praktikan sudah siap, yaitu mahasiswa menyiapkan silabus pembelajaran dan Rencana Pelaksanaan Pembelajaran (RPP) sudah terpenuhi dengan lengkap. Namun dalam melaksanakan kegiatan pembelajaran dengan komponen keterampilan dasar mengajar terdiri dari 8 keterampilan yaitu keterampilan membuka dan menutup pembelajaran, keterampilan menjelaskan, keterampilan mengadakan variasi, keterampilan memberi penguatan, keterampilan bertanya, keterampilan mengelola kelas, keterampilan mengajar kelompok kecil dan perorangan, keterampilan membimbing diskusi kelompok kecil masih belum dapat dilakukan dengan baik, terlihat pada komponen mengelola kelas mahasiswa pratikan tidak memberikan teguran kepada peserta didik karena rasa tidak enak karena peserta didik adalah teman sesama mahasiswa, dan membuat simpulan dari hasil diskusi kelompok untuk menutup diskusi.
\end{abstract}

Kata kunci: Analisis, Kesiapan, Pendidik Profesional. 


\section{A. PEndahuluan}

\section{Latar Belakang Masalah}

Masalah yang berkaitan dengan tugas seorang pendidik menjadi pembicaraan di masyarakat sehingga aspek kompetensi yang harus dimiliki pendidik menjadi penilaian publik tersebut. Rendahnya mutu pembelajaran yang disebabkan oleh tuntutan bagi seorang pendidik, minimnya sarana dan prasarana di sekolah, dan rendahnya kompetensi yang dimiliki oleh pendidik juga menyebabkan proses dalam pembelajaran tidak berjalan dengan optimal. Dalam aspek lain, pendidik dituntut untuk dapat memberikan yang terbaik bagi peserta didiknya. Padahal untuk mencapai tujuan pendidikan tidak terjadi semudah membalikkan telapak tangan, tetapi diperlukan proses yang panjang dan kemauan yang kuat dari seorang pendidik itu sendiri.

Dalam menyiapkan hal ini, Prodi PGMI melalui beberapa mata kuliah memberikan seperangkat pengetahuan dan keterampilan kepada mahasiswanya tentang proses belajar mengajar dan atau kegiatan lainnya dalam mata kuliah teori dan praktik. Mata kuliah praktik salah satunya adalah mata kuliah pembelajaran mikro (microteaching). Pada mata kuliah ini mahasiswa dipastikan akan mendapatkan pengalaman-pengalaman yang berkaitan dengan keterampilan dasar mengajar.

Mata kuliah pembelajaran mikro (microteaching) merupakan mata kuliah wajib yang harus diambil mahasiswa Prodi PGMI Fakultas Tarbiyah dan Keguruan UIN Raden Intan Lampung yang tersaji pada semester enam dan merupakan mata kuliah praktikum yang bersifat aplikatif dan terpadu dari keseluruhan teori dan pengalaman belajar sebelumnya. Pembelajaran mikro ini merupakan program pelatihan untuk menyiapkan mahasiswa agar mengusai kompetensi keguruan, sehingga dapat mengemban tugas dan tanggung jawab secara profesional. Berdasarkan hasil penelitian yang telah dilakukan sebelumnya, pembelajaran mikro ini merupakan awal mula dari segenap kemampuan yang telah diperoleh mahasiswa selama belajar dalam proses perkuliahan. Mahasiswa yang telah mengambil dan lulus mata kuliah pembelajaran mikro (microteaching) dapat dikatakan telah siap dalam melaksanakan keterampilan dasar mengajar 
dikarenakan sebelumnya mahasiswa sudah mendapatkan mata kuliah teori yang menjadi dasar pedoman pelaksanakan pembelajaran mikro.

Keberhasilan dalam pembelajaran mikro ini terkait dan ditentukan oleh kemampuan yang dimiliki oleh mahasiswa sebagai calon pendidik. Walaupun mahasiswa sudah pernah diberikan teori dan dilatih menyusun perangkat pembelajaran pada mata kuliah perencanaan pembelajaran dan strategi pembelajaran, namun singkatnya waktu yang diberikan dan materi yang perlu disampaikan juga bermacam-macam, membuat mahasiswa tidak dapat menyiapkan perangkat pembelajaran dengan baik.

Penelitian yang dilakukan oleh Lisa Purwati (2011) pengaruh positif dan signifikan praktik pengalaman lapangan dan konsep diri akademik terhadap kesiapan mahasiswa pendidikan akuntansi menjadi guru yaitu sebesar 51,5\%. Sedangkan sisanya $48,5 \%$ besarnya kesiapan mahasiswa menjadi guru dipengaruhi oleh variabel lain yang tidak diteliti dalam penelitian ini. Selajutnya Budi Irawansyah dengan judul penelitian “Analisis Kesiapan Mahasiswa Alumni Program Studi Pendidikan Matematika STAIN Zawiyah Cot Kala Langsa menjadi Guru Profesional". Hasil penelitiannya menyatakan ada 7 faktor yang mempengaruhi kesiapan mahasiswa alumni Prodi PMA menjadi guru profesional, yaitu (1) faktor kemampuan diri, (2) faktor citra diri, (3) faktor pendukung informasi mengajar, kondisi keluarga, dan bimbingan vokasional, (4) faktor bawaan, yaitu nilai, keadaan fisik, dan bakat, (5) faktor perilaku yaitu sikap, kemandirian, dan minat, (6) faktor akademik, yaitu kedisiplinan dan prestasi belajar, dan (7) faktor cita-cita dan potensi diri dan peluang masuk kerja serta kecerdasaan. Faktor yang paling besar pengaruhnya terhadap kesiapan menjadi guru adalah faktor kemampuan yang mempunyai eigenvalue 5.515 dan mampu memberikan kontribusi 26,262\%. Faktor ini terdiri dari keterampilan, pengalaman mengajar, dan kreativitas.

Menurut hasil penelitian Astri Sutisnawati (2017) bahwa keterampilan mengajar mahasiswa calon guru SD didapatkan criteria penilaian ideal keterampilan dasar mengajar berada pada rentang skor 74,80<X $<92,41$ dengan kategori baik. Dari ketujuh aspek yang diujikan terdasapat dua aspek yang memiliki kriteria cukup yaitu aspek alokasi waktu dan keterampilan menutup 
pembelajaran, sementara aspek yang lain berada pada kategori baik. Kesiapan mahasiswa menjadi calon pendidik profesional dipengaruhi oleh faktor internal maupun faktor eksternal. Motivasi dan kurang optimalnya kemampuan mahasiswa dalam mengatasi situasi dan kondisi di dalam kelas, ketidaksiapan dari mahasiwa sendiri karena minimnya keterampilan dasar yang dikuasai menjadi permasalahan yang dihadapi ( Gunawan, 2016). Oleh karena itu, dipandang perlu untuk dilakukan suatu penelitian untuk menganalisis kesiapan mahasiswa Prodi PGMI sebagai calon pendidik pada jenjang pendidikan dasar (SD/MI) melalui mata kuliah pembelajaran mikro agar mahasiswa lebih siap untuk menjadi seorang pendidik yang profesional.

\section{Rumusan Masalah}

Rumusan masalah pada penelitian ini adalah:

a. Bagaimanakah kesiapan mahasiswa Prodi Pendidikan Guru Madrasah Ibtidaiyah Fakultas Tarbiyah dan Keguruan UIN Raden Intan Lampung dalam merencanakan pembelajaran pada pembelajaran mikro?

b. Bagaimanakah kesiapan mahasiswa Prodi Pendidikan Guru Madrasah Ibtidaiyah Fakultas Tarbiyah dan Keguruan UIN Raden Intan Lampung melaksanakan kegiatan pembelajaran pada pembelajaran mikro?

\section{Tujuan Penelitian}

Penelitian ini bertujuan untuk mendeskripsikan:

a. Kesiapan mahasiswa Prodi Pendidikan Guru Madrasah Ibtidaiyah Fakultas Tarbiyah dan Keguruan UIN Raden Intan Lampung dalam perencanaan pembelajaran pada pembelajaran mikro.

b. Kesiapan mahasiswa Prodi Pendidikan Guru Madrasah Ibtidaiyah Fakultas Tarbiyah dan Keguruan UIN Raden Intan Lampung melaksanakan kegiatan pembelajaran pada pembelajaran mikro.

\section{B. LANDASAN TEORI}

\section{Kesiapan}

Menurut Kamus Besar Bahasa Indonesia (KBBI) kesiapan berasal dari kata "siap" yang berarti sudah disediakan (tinggal memakai atau menggunakan saja). Dalam kamus psikologi, kesiapan (readiness) adalah tingkat perkembangan 
dari kematangan atau kedewasaan yang menguntungkan untuk mempraktikkan sesuatu".Selanjutnya, menurut Slameto "kesiapan adalah keseluruhan kondisi seseorang yang membuatnya siap untuk memberi respon/jawaban di dalam cara tertentu terhadap situasi (Slameto, 2003: 113). Kesiapan menjadi guru profesional adalah keadaan yang menunjukkan bahwa mahasiswa sudah memenuhi persyaratan yang diwajibkan untuk menjadi pendidik.

Kompetensi menjadi modal utama untuk menentukan siap tidaknya mahasiswa menjadi tenaga pendidik. Kesiapan dalam mengajar di wujudkan dari pemahaman dasar mengajar yang merupakan faktor penentu dalam keberhasilan mengajar. Kesiapan ini harus dimiliki dan dikuasai oleh calon pendidik. Kesiapan ini menjadi modal utama bagi mahasiswa untuk melakukan pekerjaan seorang pendidik dan menentukan baik tidaknya kualitas calon pendidik yang nantinya berujung pada kualitas pendidikan.

\section{Pendidik Profesional}

Profesional berasal dari kata profesi. Sudarwan Danim menyatakan bahwa, "profesi sebagai suatu pekerjaan yang mensyaratkan persiapan spesifikasi akademi dalam waktu relatif lama di perguruan tinggi, baik di bidang sosial, eksakta, seni, dan pekerjaan ini lebih bersifat mental intelekual daripada fisik manual yang dalam mekanisme kerja dikuasai oleh kode etik" (Sudarmawan Danim, 2013). Menurut Udin Syaefuddin makna profesi secara leksikal mengandung berbagai makna dan pengertian, sebagai berikut:

a. Profesi itu menunjukkan dan mengungkapkan suatu kepercayaan (to profess means to trust), bahkan suatu keyakinan (to belief in) atas suatu kebenaran (ajaran agama) atau kredibilitas seseorang.

b. Profesi juga dapat menunjukkan dan mengungkapkan suatu pekerjaan atau urusan tertentu (a particular businnes) (Udin Syaefudin Saud, 2013: 3)

Berdasarkan teori di atas dapat disimpulkan bahwa profesi itu pada hakikatnya adalah merupakan suatu pekerjaan tertentu yang menuntut persyaratan khusus dan istimewa sehingga meyakinkan seseorang untuk mendapatkan kepercayaan dari orang yang memerlukannya. Kompetensi profesional pendidik adalah seperangkat pengetahuan, keterampilan, pengalaman yang dimiliki dan 
dikuasai oleh pendidik dalam menjalankan tugasnya (jabatan atau pekerjaannya) sebagai pendidik.

Tenaga pendidik yang profesional harus selalu mengikuti perkembangan zaman dan dapat mengembangkan diri secara terus menerus. Pengembangan harus disesuaikan dalam bidang profesinya, agar bersinergi dengan tugas dan tanggung jawabnya. Undang-undang nomor 14 tahun 2005 tentang Guru dan Dosen pada bab IV pasal 10 telah menegaskan tentang kompetensi pendidik dan tenaga kependidikan. Kompetensi tersebut, yaitu kompetensi pedagogik, profesional, kepribadian, dan sosial. Kompetensi merupakan suatu standar keilmuan yang mutlak dimiliki oleh penyandang suatu profesi (Undang-undang Nomor 14, 2013 : 13). Oleh karena itu, mahasiswa yang akan menjadi calon pendidik harus bisa menguasai dan mengimplementasikan keempat kompetensi tersebut.

\section{Pembelajaran Pembelajaran Mikro (Microteaching)}

Microteaching berasal dari dua kata, yaitu micro dan teaching. Micro berarti kecil, terbatas, sempit, dan sedikit. Teaching berarti mengajar. Jadi microteaching adalah kegiatan mengajar yang segala aspek pengajarannya diperkecil atau disederhanakan (Barnawi dan M. Arifin, 2016: 16). Cooper dan Allen (1971), mendefinisikan "Pembelajaran Mikro (Microeacthing) adalah suatu situasi pembelajaran yang dilaksanakan dalam waktu dan jumlah peserta didik yang terbatas, yaitu selama 5 - 20 menit dengan jumlah peserta didik sebanyak 3 -10 orang".

Mc. Laughlin dan Moulton (1975) mendefinisikan " Micro Teaching is a Performance training method designed to isolated the component part of teaching process, so that the trainee can master each component one by one in a simplified teaching situation”. Selanjutnya Waskito (1977) mendefinisikan “Micro Teaching adalah suatu metode belajar mengajar atas dasar performance yang tekniknya dengan cara mengisolasikan komponen - komponen proses belajar mengajar sehingga calon pendidik dapat menguasai setiap komponen satu per satu dalam situasi yang disederhanakan atau dikecilkan” (Zainal Asril, 2015: 43). Dapat disimpulkan bahwa pembelajaran mikro (Microtaching) adalah "Salah satu praktik mengajar dalam lingkup yang terbatas (mikro) untuk mengembangkan dasar keterampilan mengajar (Base Teaching Learning) yang dilaksanakan secara 
terisolasi dalam situasi yang disederhanakan atau dikecilkan". Dalam pembelajaran mikro dapat dilakukan dalam bentuk sebenarnya, misalnya dengan menggunakan peserta didik sebenarnya menjadi peserta didik, atau dapat juga dilakukan dalam bentuk simulasi, yaitu menggunakan mahasiswa sebagai peserta didik.

Selanjutnya, terdapat tujuh karakteristik pembelajaran mikro, yaitu: (1) Real Teaching; (2) Specific control of teaching practice; (3) Specific teaching skills; (4) Scaled down teaching; (5) Individualized device; (6) Providing feedback; (7) Device for preparing teachers (Daryanto, 2014: 40-42). Menurut Sukirman prinsip yang menjadi aturan atau ketentuan dalam penerapan pembelajaran mikro, antara lain sebagai berikut:

a. Fokus pada penampilan; yang menjadi sasaran utama dalam microteaching ialah penampilan setiap peserta yang dilatih. Penampilan yang dimaksud adalah perilaku atau tingkah laku peserta (calon pendidik/pendidik) dalam melatihkan setiap jenis keterampilan mengajarnya. Penampilan menunjukkan pada performance seseorang secara konkret bisa diliat atau diamati.

b. Spesifik dan konkret; jenis keterampilan yang dilatihkan harus terpusat pada setiap jenis keterampilan mengajar yang dilakukan bagian demi bagian.

c. Cara yang dilakukan peserta harus dilakukan dengan optimal memfokuskan pada keterampilan mengajar.

d. Umpan balik; maksudnya proses memberikan balikan (komentar, saran, solusi pemecahan, dan lain-lain) yang didasarkan pada hasil pengamatan dari penampilan yang dilatih.

e. Keseimbangan; ketika memberikan komentar atau saran harus seimbang antara kelebihan dan kekurangan peserta yang dilatih tersebut.

f. Ketuntasan; keterampilan yang maksimal dari apa yang dipelajarinya. Latihan dapat dilakukan sekali, atau dua kali sampai yang dilatih dapat memberikan hasil capaian yang memuaskan.

g. Maju berkelanjutan; siapapun yang dilatih dengan microteaching, harus mau belajar secara terus menerus, tanpa ada batasnya (life long of education) (Dadang Sukirman, 2012: 65-67). 
Perlu dipahami bahwa pembelajaran mikro ini berusaha untuk mengembangkan penguasaan sejumlah keterampilan dasar mengajar. Pembelajaran mikro bisa dianggap sebagai model pelatihan untuk menghasilkan calon guru yang sama dengan penampilan yang standar sesuai dengan yang diharapkan.

\section{Standar Proses Pembelajaran}

Peraturan Menteri Pendidikan Nasional No. 41 Tahun 2007 yang meliputi perencanaan proses pembelajaran, pelaksanaan proses pembelajaran, penilaian hasil pembelajaran, dan pengawasaaan proses pembelajaran (Permendiknas No. 19, 2007: 2). Selanjutnya sekolah yang sudah menggunakan kurikulum 2013, standar proses yang digunakan seperti yang tercantum dalam Peraturan Menteri Pendidikan Nomor 65 Tahun 2013 tentang Standar Proses pendidikan meliputi perencanaan proses pembelajaran, pelaksanaan proses pembelajaran, penilaian hasil pembelajaran, dan pengawasaan proses pembelajaran (Permendiknas No. 65, 2013: 2).

Kedua peraturan tersebut tetap dipakai dan masih menjadi acuhan bagi sekolah-sekolah yang ada. Oleh karena itu, dalam penelitian ini peneliti masih memakai kedua acuhan tersebut sebagai dasar teori penelitian. Peraturan Pemerintah Nomor 41 tahun 2007 dan sebagai berikut:

a. Perencanan proses pembelajaran

Perencanaan proses pembelajaran ini meliputi silabus dan rencana pelaksanaan pembelajaran (RPP) sesuai dengan Peraturan Menteri Nomor 41 tahun 2007 yang memuat identitas mata pelajaran, standar kompetensi (SK), kompetensi dasar (KD) indikator pencapaian kompetensi, tujuan pembelajaran, materi ajar, alokasi waktu, metode pembelajaran, kegiatan pembelajaran, penilaian pembelajaran, penilaian hasil belajar, dan sumber belajar.

b. Pelaksanaan proses pembelajaran

Pelaksanaan pembelajaran merupakan implementasi dari rencana pelaksanaan pembelajaran (RPP). Pelaksanaan ini meliputi kegiatan pendahuluan, kegiatan inti, dan kegiatan penutup. 
c. Penilaian hasil pembelajaran

Penilaian ini dilakukan untuk mengukur tingkat pencapaian hasil pembelajaran, kompetensi yang dicapai peserta didik, serta dapat digunakan sebagai penyusunan laporan kemajuan hasil belajar, dan memperbaiki proses pembelajaran.

Peraturan Pemerintah Nomor 65 tahun 2013 sebagai berikut:

a. Perencanan proses pembelajaran

Dalam silabus komponen yang dimuat adalah; identitas mata pelajaran, identitas sekolah, Kompetensi Inti (KI), Kompetensi Dasar (KD), tema (khusus SD/MI/SDLB/Paket A), materi pokok, pembelajaran, penilaian, alokasi waktu, sumber belajar. Komponen RPP meliputi identitas sekolah, identitas mata pelajaran, kelas/semester, materi pokok, alokasi waktu, tujuan pembelajaran, kompetensi dasar dan indikator pencapaian kompetensi, materi pembelajaran, metode pembelajaran, media pembelajaran, sumber belajar, langkah-langkah pembelajaran, penilaian hasil belajar, prinsip penyusunan RPP (perbedaan individual peserta didik, partisipasi aktif peserta didik, berpusat pada peserta didik, pengembangan budaya membaca dan menulis, pemberian uman balik, penekanan dan keterkaitan antara komponen dalam silabus, mengakomodasi pembelajaran tematik, dan penerapan teknologi informasi dan komunikasi).

b. Pelaksanaan proses pembelajaran

Pelaksanaan pembelajaran merupakan implementasi dari rencana pelaksanaan pembelajaran (RPP). Pelaksanaan ini meliputi kegiatan pendahuluan, kegiatan inti, dan kegiatan penutup.

c. Penilaian hasil pembelajaran

Penilaian ini dilakukan dengan menggunakan pendekatan penilaian otentik (authentic assessment) yang menilai kesiapan peserta didik, proses, dan hasil belajar secara utuh.

\section{Keterampilan Dasar Mengajar}

Dalam mengajar membutuhkan seni dan bakat karena mengajar adalah suatu kegiatan yang kompleks, yang mengandung banyak unsur di dalamnya. Mengajar juga memerlukan keterampilan yang dilandasi seperangkat teori, yang 
dapat dikembangkan berlandaskan situasi dan materi yang akan disampaikan. Hal ini menuntut keterampilan dasar mengajar seorang guru. Keterampilan mengajar merupakan kompetensi profesional guru yang cukup kompleks, karena merupakan integrasi keilmuan dari berbagai kompetensi guru secara utuh.

Pendapat Uzer Usman dalam bukunya "Menjadi Guru Profesional" mengemukakan 8 (delapan) komponen keterampilan dasar mengajar. Sementara itu Barnawi menjelaskan keterampilan dasar mengajar yang perlu dipelajari seorang teacher trainee ada delapan keterampilan, yaitu: (1) keterampilan membuka dan menutup pembelajaran; (2) keterampilan menjelaskan; (3) keterampilan mengadakan variasi; (4) keterampilan memberikan penguatan; (5) keterampilan bertanya; (6) keterampilan mengelola kelas; (7) keterampilan mengajar kelompok kecil dan perorangan; serta (8) keterampilan membimbing diskusi kelompok kecil (Barnawi dan M. Arifin, 2016: 127-128).

\section{METODE PENELITIAN}

Secara umum metode penelitian diartikan sebagai cara ilmiah untuk mendapatkan data penelitian dengan tujuan dan kegunaan tertentu. Karena fokus penelitian ini bertujuan untuk memperoleh gambaran di lapangan tentang analisis kesiapan mahasiswa Prodi PGMI menjadi pendidik profesional, maka penelitian ini menggunakan deskriptif dengan pendekatan kualitatif.

Menurut Creswll (dalam Sugiyono) menjelaskan bahwa penelitian kualitatif adalah "sebuah proses penyelidikan untuk memahami masalah sosial berdasarkan pencapaian holistik yang dibentuk dengan kata, melaporkan pandangan informasi secara terperinci dan disusun dalam sebuah latar ilmiah" (Sugiono, 2011: 15). Penelitian ini bertujuan untuk menggambarkan, menguraikan, dan mendeskripsikan tentang kesiapan mahasiswa Prodi Pendidikan Guru Madrasah Ibtidaiyah (PGMI) FTK UIN Raden Intan Lampung dalam melaksanakan praktik pada mata kuliah pembelajaran mikro.

Variabel penelitian ini yaitu kesiapan mahasiswa Prodi PGMI dalam melaksanakan praktik pada mata kuliah pembelajaran mikro yang meliputi kompetensi pedagogik dalam keterampilan dasar mengajar, yaitu merencanakan pembelajaran dan melaksanakan kegiatan pembelajaran. Subyek pada penelitian 
ini adalah mahasiswa prodi PGMI yang mengambil mata kuliah pembelajaran mikro (microteaching) pada semester genap 2016/2017.

Dalam penelitian ini teknik sampling yang digunakan adalah teknik purposive sampling Sampel dalam penelitian ini yang diambil sebanyak 5 orang dari kelas yang berbeda. Pemilihan sampel berdasarkan pada kriteria, yaitu atas rekomendasi dosen pembimbing mata kuliah, kebersediaan mahasiswa untuk diteliti, perbedaan kemampuan mahasiswa praktikan laki-laki dan mahasiswa praktikan perempuan.

Teknik pengumpulan data yang digunakan adalah teknik dokumentasi dan observasi. Dokumentasi data berupa silabus, Rencana Pelaksanan Pembelajaran (RPP), rancangan penilaian, video rekaman mahasiswa latihan pembelajaran mikro, dan catatan yang berkaitan pada proses pembelajaran mikro. Dalam penelitian ini model analisis data yang digunakan adalah analisis interaktif yang dikemukakan oleh Miles dan Huberman. Analisis interaktif yaitu suatu analisis data kualitatif yang terdiri dari tiga alur kegiatan yaitu (1) reduksi data (2) penyajian data (3) penarikan kesimpulan /verifikasi.

\section{HASIL PENELITIAN DAN PEMBAHASAN}

Berdasarkan data-data yang telah didapat baik menggunakan lembar dokumentasi dan rekaman video pembelajaran mikro, dapat dilakukan pembahasaan terhadap masalah penelitian sebagai berikut:

\section{Kesiapan mahasiswa Prodi PGMI FTK UIN Raden Intan Lampung dalam Perencanakan Pembelajaran Pada Pembelajaran Mikro}

Untuk mencapai tujuan pembelajaran yang diharapkan, diperlukan langkah-langkah salah satunya adalah perencanaan pembelajaran. Perencanaan yang dibuat sebagai pedoman yang digunakan dalam melaksanakan kegiatan pembelajaran. Pendidik bertanggung jawab langsung terhadap upaya terlaksananya apa yang ada dalam perencanaan pembelajaran, karena pendidik yang menyusun perencanaan pembelajaran dan langsung melaksanakan kegiatan pembelajaran.

Data yang didapat tentang perencanaan pembelajaran mahasiswa Prodi PGMI pada pembelajaran mikro diperoleh melalui dokumentasi yang ada. Untuk 
silabus semua mahasiswa tidak menyusunnya akan tetapi menggunakan silabus yang sudah ada dari pemerintah, dan rencana pelaksanaan pembelajaran (RPP) yang menyusun mahasiswa sendiri berdasarkan dari silabus yang ada. RPP yang disusun berpedoman pada kurikulum KTSP dan Kurikulum 2013. Berdasarkan analisis lembar penilaian rencana pelaksanaan pembelajaran (RPP), secara umum mahasiswa praktikan sudah mampu menyusun RPP yang sesuai dengan ketentuan kelengkapan RPP dalam standar proses, kesesuaian tujuan pembelajaran dengan standar kompetensi, kompetensi dasar, dan indikator pencapaian kompetensi, kesesuaian materi pokok dan uraiannya dengan silabus. Sebagian besar mahasiswa sudah mempraktikan berbagai macam pendekatan, strategi dan metode pembelajaran aktif yang bervariasi, seperti Number Head Together (NHT), Picture and Picture, Talking Stick, Snowball Throwing, Critical Incident, Jigsaw, STAD, Make and Match, Team Games Tournament (TGT), Card Short, Index Card Match, Poster Comment, Everyone is a Teacher Here, dan lain sebagainya.

Setiap mahasiswa praktikan wajib melaksanakan praktik mengajar minimal 3 kali, sedangkan bagi mahasiswa yang kemampuan mengajarnya belum optimal pelaksanaanya, maka diberikan kesempatan mengulang 1 kali lagi untuk praktik. Alokasi waktu praktik yang diberikan rata-rata antara 15 -20 menit. Setiap kali mahasiswa selesai melakukan praktik mengajar, dosen pembimbing dan mahasiswa yang menjadi peserta didik memberikan umpan balik terhadap proses pembelajaran yang telah dilaksanakan. Materi pembelajaran yang dipraktikkan berupa materi mata pelajaran tingkat SD/MI. Mahasiswa praktikan harus siap dengan 12 mata pelajaran yang ada, yaitu Bahasa Indonesia SD/MI, Matematika, Ilmu Pengetahuan Alam (IPA), Ilmu Pendidikan Sosial (IPS), Pendidikan Kewarganegaraan (PKn), Fiqih, Akidah Akhlak, Qur'an Hadits, Sejarah Kebudayaan Islam, Bahasa Arab, Seni Budaya dan Keterampilan (SBK), dan Pendidikan Kesehatan, (Penjas). Oleh karena itu, pemilihan materi yang akan dipraktikan diundi secara acak. Dalam menyusun RPP sebagian mahasiswa sudah menggunakan pembelajaran tematik untuk kurikulum 2013, sebagian lagi tetap dengan menggunakan mata pelajaran untuk kurikulum KTSP.

Semua mahasiswa praktikan menyusun RPP dengan komponen yang sesuai dengan syarat yang ada pada standar proses yang meliputi identitas mata 
pelajaran, standar kompetensi, kompetensi dasar, indikator pencapaian kompetensi, tujuan pembelajaran, materi ajar, alokasi waktu, metode pembelajaran, kegiatan pembelajaran, penilaian hasil belajar, dan sumber belajar. Semua mahasiswa sudah menyusun RPP dengan lengkap komponenkomponennya. Dalam penyusunan RPP mahasiswa praktikan sudah memperhatikan perbedaan individu dengan menggunakan berbagai macam strategi pembelajaran kooperatif dalam pembelajaran. Dalam mendorong partisipasi aktif peserta didik, mahasiswa praktikan sudah menyusun dalam langkah-langkah pembelajaran untuk berdiskusi secara kelompok maupun individual.

Dalam mengembangkan aspek membaca dan menulis peserta didik, mahasiswa praktikkan melakukan dalam aktivitas yang dilakukan selama pembelajaran. Dalam RPP mahasiswa praktikan juga merencanakan membahas lembar kerja siswa dan dilanjutkan dengan memberikan pekerjaan rumah kepada peserta didik. Komponen yang dilakukan juga sebagian besar sudah terpadu dan terkait satu sama lain. Tetapi dalam penyusunan RPP umumnya mahasiswa praktikan belum mencantumkan alat atau bahan yang menerapkan teknologi dan komunikasi.

Pada penyusunan RPP praktikkan pertama, sebagian besar mahasiswa belum dapat menguraikan secara detail langkah-langkah pembelajaran yang akan dilaksanakannya, sehingga pada waktu praktiknya mahasiswa masih kebingungan ketika harus menyiapkan apersepsi secara mendadak. Selain itu, pada bagian penilaian masih belum sesuai dengan indikator hasil belajar, jenis tagihan, dan bentuk instrumen serta belum disertai dengan kunci jawaban.

Selanjutnya, berdasarkan hasil pada praktikan pertama, dosen pembimbing memberikan masukan dan perbaikan pada RPP praktikkan kedua, sehingga mahasiswa praktikkan sudah dapat menguraikan secara detail langkah-langkah pembelajaran dengan benar. Berdasarkan analisis data dan pembahasan yang didapat, mahasiswa sudah dapat merencanakan pembelajaran dengan baik sesuai dengan standar proses baik komponen maupun prinsip-prinsip penyusunannya sudah terpenuhi. Perencanaan ini dilakukan untuk mengantar mahasiswa 
praktikkan melakukan proses belajar mengajar yang optimal sehingga tercapai tujuan pembelajaran yang diharapkan.

\section{Kesiapan mahasiswa Prodi PGMI FTK UIN Raden Intan Lampung Melaksanakan Kegiatan Pembelajaran Pada Pembelajaran Mikro.}

Data tentang kemampuan melaksanakan kegiatan pembelajaran yang dilaksanakan mahasiswa praktikkan diperoleh melalui dokumentasi berupa rekaman video pelaksanaan pembelajaran dan observasi. Aspek yang diamati dalam latihan pelaksanaan pembelajaran ada 8 komponen yaitu keterampilan dasar mengajar secara terpadu, yang meliputi, (1) keterampilan membuka dan menutup pembelajaran; (2) keterampilan menjelaskan; (3) keterampilan mengadakan variasi; (4) keterampilan memberikan penguatan; (5) keterampilan bertanya; (6) keterampilan mengelola kelas; (7) keterampilan mengajar kelompok kecil dan perorangan; dan (8) keterampilan membimbing diskusi kelompok kecil.

Data-data tersebut dapat diuraikan sebagai berikut:

a. Membuka pelajaran dan menutup pelajaran

Secara umum mahasiswa sudah terampil membuka pelajaran dan menutup pembelajaran, tetapi aspek kegiatan awal yang paling esansial yaitu apersepsi masih ada dua mahasiswa praktikan tidak melakukanya, dan juga ada melakukan apersepsi tetapi kurang sesuai dengan materi yang akan disampaikan. Apersepsi ini dapat dilakukan mengajukan pertanyaanpertanyaan yang berkaitan dengan materi yang akan dipelajari, mengkomunikasikan tujuan pembelajaran yang akan dicapai pada pertemuan tersebut dan memberikan gambaran kegiatan yang akan dilakukan didalamnya. Oleh karena itu, mahasiswa belum mampu mengawali kegiatan pembelajaran dengan baik. Dalam menutup pembelajaran, keterampilan mahasiswa praktikan adalah membuat rangkuman berupa pokok-pokok persoalan yang telah dipelajari dengan melakukannya sendiri dan memberikan tes tertulis sebagai alat evaluasi pembelajaran. Keterampilan yang belum dikuasai pada kegiatan penutup ini adalah memberikan refleksi hasil pembelajaran.

b. Dalam menjelaskan dan penyampaian materi pembelajaran, mahasiswa praktikkan sudah mampu menyampaikannya secara tepat, dengan 
menggunakan ilustrasi atau contoh yang sesuai dengan materi. Penyampaian materi diberikan secara berurutan sesuai dengan langkah yang ada dalam RPP yang sudah dibuat, mahasiswa juga menekankan hal-hal yang penting pada materi. Semua mahasiswa praktikkan dapat menyampaikan materi dengan lancar, namun masih mahasiswa praktikkan masih perlu melatih lagi kemampuannya dalam menyampikan materi semenarik mungkin agar menarik minat peserta didik dan lebih mendalami lagi materi yang akan disampaikan. Hal ini agar peserta didik dapat memahaminya dengan mudah.

c. Mahasiswa juga sudah terampil dalam mengadakan variasi dalam mengajar, seperti gaya mengajar yaitu berkenaan dengan suara, mimik, dan gerak. Sudah terampil dalam menggunakan media dan pola interaksi, serta pemberian kesempatan peserta didik untuk berpikir. Dalam mengadakan variasi mengajar, keterampilan yang dikuasai mahasiswa praktikkan adalah menggunakan perubahan volume suara dan melakukan posisi di dalam kelas dari depan ke tengah atau kebelakang kelas. Keterampilan yang belum dikuasai adalah menggunakan variasi gerakan badan (gestures) untuk memperjelas materi pembelajaran dan penggunaaan variasi media atau alat pembelajaran.

d. Dalam aspek penguatan, mahasiswa sudah dapat melakukannya dengan baik, secara verbal maupu nonverbal. Bentuk nonverbal dengan cara memberikan senyuman terhadap respon positif peserta didik, menganggukan kepala, mengangkat jempol, dan memberikan reward dalam bentuk hadiah (benda kecil). Keterampilan yang belum dikuasai adalah memberikan penguatan secara verbal dengan memberikan kata-kata pujian atau penghargaan.

e. Dalam bertanya mahasiswa praktikkan mengajukan pertanyaan dengan jelas yang berkaitan dengan permasalahan, mengajukan pertanyaan terlebih dahulu secara klasikal dilanjutkan dengan menunjuk salah satu peserta didik, memberikan waktu yang cukup bagi peserta didik untuk berpikir dan menemukan jawaban, dan mengajukan kembali pertanyaan untuk mengali pengetahuan peserta didik. Keterampilan yang belum dikuasai adalah mengajukan pertanyaan secara merata kepada peserta didik. Keterampilan bertanya ini penting dikuasai seorang pendidik karena dapat menciptakan 
suasana pembelajaran lebih bermakna. Pembelajaran akan terasa menjenuhkan jika pendidik hanya mejelaskan materi pembelajaran tanpa diselingi dengan pertanyaan.

f. Dalam mengelola kelas, agar kelas menjadi kondusif dan tenang, mahasiswa praktikan sudah terampil melakukannya. Mengelola kelas sesuai dengan strategi yang digunakan, mengatur peserta didik sesuai dengan strategi yang digunakan, memusatkan perhatian dan konsentrasi peserta didik terhadap materi yang disampaikan, namun terkadang mahasiswa tidak memberikan teguran terhadap peserta didik yang tidak memperhatikan pelajaran. Hal ini karena faktor rasa tidak enak karena yang ditegur walaupun sebagai peserta didik tetaplah temannya sesama mahasiswa. Selanjutnya, dalam mengatur alokasi waktu yang tersedia, mahasiswa masih belum dapat melakukan dengan terampil, karena waktu yang digunakan untuk praktik dalam pembelajaran mikro ini berkisar 15-20 menit. Faktor waktu ini juga menyebabkan materi yang banyak tidak dapat tersampikan dengan baik, mahasiswa terburu-buru dalam menyelesaikan proses pembelajaran.

g. Dalam kegiatan kelompok dan perorangan, keterampilan yang dikuasai mahasiswa praktikkan adalah menyebarkan kesempatan untuk berpartisipasi kepada peserta didik, agar tidak terjadi monopoli dalam diskusi dan menguraikan dan memperluas pandangan peserta didik dengan memberikan informasi tambahan. Terkadang mahasiswa membimbing kelompok kecil dalam memecahkan kesulitan dengan cara memberikan saran atau pertanyaan. Keterampilan yang belum dikuasai adalah memperjelas tujuan atau topik yang akan dicapai dalam diskusi untuk memusatkan perhatian peserta didik, membimbing kelompok kecil dan memberikan simpulan dari hasil diskusi kelompok yang telah dilaksanakan.

h. Dalam membimbing diskusi kelompok kecil, mahasiswa praktikkan kadangkadang membimbing kelompok kecil dalam memecahkan kesulitan, mengatasi gangguan belajar di dalam kelas. Hal tersebut dilakukan agar diskusi dapat berjalan dengan baik. Untuk dapat menentukan tercapai tidaknya tujuan pembelajaran, perlu dilakukan usaha atau tindakan penilaian. Sejauh mana keberhasilan pendidik menyampaikan materi dan sejauh mana 
peserta didik menyerap materi yang telah disajikan dapat diperoleh datanya melalui penilaian.

\section{E. KESIMPULAN}

Berdasarkan hasil analisis data dan pembahasan, maka dapat disimpulkan bahwa:

1. Berdasarkan hasil analisis penelitian dapat disimpulkan bahwa dalam melakukan perencanaan pembelajaran mahasiswa praktikan sudah siap, yaitu mahasiswa menyiapkan silabus pembelajaran dan Rencana Pelaksanaan Pembelajaran (RPP) sudah terpenuhi dengan lengkap.

2. Dalam melaksanakan kegiatan pembelajaran dengan komponen keterampilan dasar mengajar terdiri dari 8 keterampilan yaitu keterampilan membuka dan menutup pembelajaran, keterampilan menjelaskan, keterampilan mengadakan variasi, keterampilan memberi penguatan, keterampilan bertanya, keterampilan mengelola kelas, keterampilan mengajar kelompok kecil dan perorangan, keterampilan membimbing diskusi kelompok kecil masih belum dapat dilakukan dengan baik, terlihat pada komponen mengelola kelas mahasiswa pratikan tidak memberikan teguran kepada peserta didik karena rasa tidak enak karena peserta didik adalah teman sesama mahasiswa, dan membuat simpulan dari hasil diskusi kelompok untuk menutup diskusi.

\section{F. DAFTAR PUSTAKA}

Anita Diah Prasetyana dkk. Analisis Keterampilan Dasar Mengajar Mahasiswa Pendidikan Matematika Dalam Pembelajaran Mikro (Studi Kasus pada Mahasiswa Pendidikan Matematika FKIP UNS Tahun Kademik 20122013). (Jurnal Magister Matemika UNS), Vol.3 No.4. 2015.

Astri Sutisnawati. Analisis Keterampilan Dasar Mengajar Mahasiswa Calon Guru Sekolah Dasar. Jurnal MPD Volume 8, Nomor 1 Februari. 2017.

Barnawi dan M. Arifin. 2016. Micro Teaching. Yogyakarta: Ar-Ruzz Media.

Budi Irawansyah. "Analisis Kesiapan Mahasiswa Alumni Program Studi Pendidikan Matematika STAIN Zawiyah Cot Kala Langsa menjadi Guru Profesional”, Jurnal. 2014.

Dadang Sukirman. 2012. Pembelajaran Micro Teaching. Jakarta; Direktorat Jenderal Pendidikan Islam. Kementerian Agama RI. 
Daryanto. 2014. Pendekatan Pembelajaran Saintifik Kurukulum 2013. Yogyakarta, Gava Media.

Entri Sulistari, Andri Ayu Madyaningrum, Madiya. 2013. "Perbedaan Kesiapan Menjadi Guru Profesional Dikalangan Mahasiswa Pendididkan Ekonomi FKIP UKSW Ditinjau Dari Ekspektasi Setelah Lulus".

Lisa Purwati "Pengaruh Praktik Pengalaman Lapangan dan Konsep Diri Akademik Terhadap Kesiapan Mahasiswa Menjadi Guru (Studi Pada Mahasiswa Prodi Pendidikan Akuntansi Fakultas Ekonomi Angkatan 2011). Skripsi.

Mills, Mattew B. dan A. Michael Huberman. 2007. Analisis Data Kualitatif. Jakarta: Universitas Indonesia.

Moh. Uzer Usman. 2013. Menjadi Guru Profesional. Bandung: Remaja Rosdakarya.

Moleong, J. Lexy. 2005. Metodologi Penelitian Kualitatif. Bandung: Rosda.

Salinan Permendiknas Nomor 19 Tahun 2007 (didownload tanggal 8 Agustus 2017).

Salinan Permendikbud Nomor 65 Tahun 2013. (didownload tanggal 8 Agustus 2017).

Sugiyono. 2011. Metodologi Penelitian, Pendekatan Kuantitatif, Kualitatif, dan $R \& D$, Bandung: Alfabeta.

Slameto. 2003. Belajar dan Faktor-faktor yang Mempegaruhinya. Jakarta: Rineka Cipta.

Udin Syaefudin Saud. 2013. Pengembangan Profesi Guru, Bandung: Alfabeta.

UU No. 20 tahun 2003 tentang Sistem Pendidikan Nasional.

Undang-undang Nomor 14 Tahun 2005 Tentang Guru dan Dosen, Bab I Ketentuan Umum, pasal 1 nomor (1).

Zai nal Asril. 2015. Microteaching. Jakarta: RajaGrafindo Persada. 